\title{
Frances Power Cobbe on Brutes, Women, and the Irish (Human) Landscape: Ethics, Environment, and Imperialism
}

\author{
María José Carrera \\ Universidad de Valladolid, Spain
}

Copyright (c) 2020 by María José Carrera. This text may be archived and redistributed both in electronic form and in hard copy, provided that the author and journal are properly cited and no fee is charged for access.

\begin{abstract}
This essay focuses on how the Irish philanthropist, feminist, and animal-rights defender Frances Power Cobbe (1822-1904) uses similar terms of reference and methodologies of exposition in the pamphlets and essays she published on "the claims of brutes" and on "the claims of women". Both discourses are tinged with hues of imperialism proper to her Anglo-Irish upbringing, which deploy a third, less-known interest on the part of Cobbe: "the Irish Question" (O'Connor). To make these points, the essay studies the author's autobiography and five of her essays and pamphlets: "The Rights of Man and the Claims of Brutes" (1863), "Life in Donegal" (1866), "The Evolution of the Social Sentiment" (1874), "Wife-Torture in England" (1878), and Light in Dark Places (1883).
\end{abstract}

Key Words. Frances Power Cobbe, Antivivisection, Wife-torture, Heteropathy, Ireland, Imperialism.

Resumen. El presente ensayo se centra en el semejante uso que la filantropista, feminista y defensora de los animales irlandesa, Frances Power Cobbe (1822-1904) hace de términos de referencia y metodologías expositivas en los panfletos y ensayos que publicó sobre "los derechos de los animales" y "los derechos de las mujeres". Ambos discursos evidencian tintes imperialistas propios de su educación anglo-irlandesa, que ponen de manifiesto un tercer interés menos conocido por parte de Cobbe: "la cuestión irlandesa" (O'Connor). Con este objetivo, el ensayo estudia la autobiografía de la autora y cinco de sus ensayos y panfletos: "The Rights of Man and the Claims of Brutes" (1863), "Life in Donegal" (1866), "The Evolution of the Social Sentiment" (1874), "Wife-Torture in England" (1878), y Light in Dark Places (1883).

Palabras clave. Frances Power Cobbe, antivivisección, tortura a la mujer, heteropatía, Irlanda, imperialismo. 
Born into the Irish gentry in Newbridge House, Dublin, home to the Cobbe family for over four centuries, the essayist, philanthropist, feminist, and animal-rights advocate Frances Power Cobbe (1822-1904) cut an interesting and influential figure in the social panorama of Victorian England. "Nothing that took place in the world of politics, history, or literature, was indifferent to her", says Blanche Atkinson in her introduction to the posthumous edition of Frances Cobbe's autobiography (xi). This essay studies how her interests, however varied, are linked in subtle ways and are indeed conditioned by her Anglo-Irish upbringing. Beginning with a brief sketch of the author as high-class girl brought up in Ireland who developed her public life in London, we analyse her discourses against the cruelty to animals at the hands of vivisectors and against the abuse suffered by women at the hands of their husbands. These discourses are not exempt from contradictions and, as we shall see, are tinged with hues of imperialism related to her Anglo-Irish upbringing, that should be linked to a third, lesserknown interest of Cobbe's, “The Irish Question". Maureen O'Connor, who has offered a seminal and pioneer analysis of Cobbe's advocacy of animal rights, has rightly pointed out the shortcomings that can be still detected in recent academic assessments of the author's life and works: "While it is gratifying and just that such a towering figure is beginning to attract long-overdue academic notice, in each of the recent studies there is a notable lack of rigour in considering two crucial aspects of her life and work: the significance of her Irish background and her work on behalf of animal rights" (O'Connor 32). Our analysis, takes into consideration O'Connor's warnings, considering Cobbe's advocacy of the rights of animals and of the rights of women, and the inconsistencies detected in both discourses in relation to her Anglo-Irish upbringing.

\section{A Girl "well born": Family Landscape}

A congratulatory address compiled on occasion of her eightieth birthday and signed by many of the people who respected her lifework provides us with a summary list of Frances Power Cobbe's philanthropic activities: she is praised for having been among the first to publicly "urge the right of women to university degrees"; for her work to promote "equality of treatment for them, in educational and other matters"; for being a pioneer in "social amelioration" promoting the Ragged Schools and Workhouse reform; for her "works on religion and ethics"; and, above all, for being "practically the first to explore the dark continent of our relations to our dumb fellow-creatures", establishing "their rights and our duty towards them" (Atkinson xvi).

The woman behind all this activity was born into a four-hundred-year-old family of English country squires who first came to Ireland in 1717. Frances Power Cobbe begins her autobiography with the claim that she was "well born" because her parents were "sound in body and in mind" (Life 3) but also in the conventional sense of the phrase: Charles Cobbe, the man who started the Anglo-Irish dynasty, was appointed Archbishop of Dublin in 1743 and built the country house of Newbridge, which is still in the family. Cobbe spent there thirty-five of her eighty-two years of life, obediently accepting the destiny that befell her as a woman (she was her parents' companion and housekeeper while her brothers were sent to English universities). Cobbe was educated at home by four successive governesses and her real education, as she stated, began with her own readings in her home library and at Archbishop Marsh's old library in Dublin (Life 69-71). Astronomy, Architecture, Heraldry, Philosophy, or Religion were among the main interests of a young girl who had "neither cares of love, or cares of money" (Life 71). Cobbe combined this intensive reading with her work as keeper of the family house after her mother's death and her interest in the condition of the poor who lived in her father's estate. 
In 1848, when she was twenty-four, her father asked her to leave Newbridge on account of her having lost her faith. Cobbe sought refuge in her brother's hired farm "in the wilds of Donegal" (Life 101). She recalls having remained in exile there for nine or ten months before her father asked her to return to Dublin (Life 137). Her presentation in her autobiography of the condition of Ireland just before and after the Famine - "the failure of the potatoes", as she puts it (Life 139) - reveals the attitude of an Anglo-Irish aristocrat who takes pity on the financial difficulties of large families but dwells on their inherent tastelessness, the poor condition of their cottages in comparison with those in Wales, or the poor table manners of young Irish girls.

After her father's death, Cobbe chose to spend her meagre annual pension travelling around the world. In one of her many visits to Italy in the 1860s and 1870s she met the Welsh sculptor Mary Lloyd, and they began a relationship of thirty-four years which, though widely accepted by friends and relatives, she kept mostly silent about in her writings: "and from that time, now more than thirty years ago, she and I have lived together. Of a friendship like this, which has been to my later life what my mother's affection was to my youth, I shall not be expected to say more" (Life 393). And no more did she say, save for the postscript added to the 1894 edition of her autobiography in 1898 in memory of her dead partner (Life 708-710). Both women set up house in London, where Cobbe began to write pamphlets on women's issues and animal's rights, newspaper articles with sketches from her travels, and several books on religion and ethics. Her literary career was hectic up to 1874 , when she undertook her antivivisection crusade.

\section{"The torture-chambers of science": The Claims of Brutes}

During her London years, before she and Mary Lyons left London for Wales in 1884, Cobbe socialized with literary men like Robert Browning and Matthew Arnold, politicians and activists like John Stuart Mill, Helen Taylor, Millicent Fawcett, and Barbara Bodichon, as well as with "the leading men of Science" (Life 482), being Charles Darwin among them. Her relationship with Darwin came to an abrupt end in 1875 with the beginning of Cobbe's antivivisectionist campaign, as she explains, not without a tinge of irony in her autobiography:

Mr. Darwin eventually became the centre of an adoring clique of vivisectors who ... plied him incessantly with encouragement to uphold their practice, till the deplorable spectacle was exhibited of a man who would not allow a fly to bite a pony's neck, standing forth before all Europe ... as the advocate of Vivisection. (Life 490-491)

This particular instance is indicative of the many feuds brought about by her staunch defence of animal rights which eventually resulted in her being charged, two years before she died, with having overdriven an old horse, a false accusation which gave her great pain in her last days (Atkinson xii-xiii).

Antivivisection is a fight that she took up in the 1870s and would never abandon until her death. She had taken the first steps as early as 1863, when news reached England that French Veterinary Faculties were operating on living animals for teaching purposes, instead of using dead carcasses, as was the usual practice in England. Cobbe was appalled at the reports describing the state the animals were left in: "hoofless, eyeless, burned, gashed, eviscerated, skinned, mutilated" (Life 620). In 1874, this kind of experiment had reached England and was much publicized by the hospitals themselves. She developed the conviction that legislation was necessary to stop that practice and in January 1875 she made a petition to the Royal Society for the Prevention of Cruelty to Animals which six hundred people signed, 
among them Thomas Carlyle, Alfred Tennyson, Robert Browning, the Primate of Ireland and three Anglican Archbishops, plus seventy-eight medical men. Although nothing came out of it, the petition urged for the establishment of restrictions on the practice of vivisection on account of the legal and moral responsibility that its practitioners incurred in.

Failed attempts at promoting a Bill to regulate the practice of vivisection being Darwin an opponent who defended the physiologists' right to do their research - were followed by the foundation of the Society for Protection of Animals Liable to Vivisection (later known as the Society for Protection of Animals from Vivisection) in December 1875. Eventually, the Vivisection Act was passed in 1876 in answer to some of their claims, but for Cobbe it looked very much like a law mainly conceived to protect the vivisectors from prosecution (Life 653). Cobbe was not willing to compromise, unlike many of her colleagues who would gladly give in to a petition for "restriction" instead of "total prohibition". The 1904 edition of her autobiography alludes to her break with that faction: she added a postscript to the chapter on the claims of brutes where she narrates the turn of her Society (known at that moment as the National Anti-Vivisection Society) towards a petition for "Lesser Measures" as intermediate steps towards prohibition. Cobbe's dissatisfaction made her withdraw from the organization and create in June 1898, only six years before her death, The British Union for the Abolition of Vivisection, a federation of societies centred in Bristol - nowadays the Cruelty Free International, which continues to fight against these problems although from a global approach.

Cobbe published abundantly to bring to public knowledge the tools and evil methods used by the vivisectors. She calculated that she wrote over four hundred pamphlets and leaflets. Her very first essay, published in answer to the reports coming from France, was "The Rights of Man and the Claims of Brutes" (1863), the first public treatise on the moral issues involved in animal torture. The essay is an attempt to answer two main questions: "What is cruelty to animals? What are the duties of man as regards the welfare of the brute, and how are they to be ranked in comparison with the duties he owes to his human fellowcreatures?" (Studies 221). The essay is organized in three main sections, dealing with the moral, humanitarian, and religious side of the question, respectively. She concludes that the experiments the vivisectors conduct, being a torture inflicted to sentient creatures, are a moral offence, "a sin against all the instincts of tenderness and pure sentiment" (Studies 250), and a sign of cruelty against the fellow-creatures (born to be happy) that God has given as companions to the human beings (born to be virtuous). We can distinguish here how, to a good extent, Frances Power Cobbe is anticipating many of the tenets of animal studies, by conceiving animals as sentient creatures and vindicating an ethical principle of equal consideration (Calarco 15).

Cobbe's vindications took an even more pressing tone after years of struggle. Therefore, in Light in Dark Places (1883), one of her last essays written on the issue, we notice a remarkable change of content and tone. If Cobbe manifested in her 1863 piece her relief at opting for an "ethical" discussion and not having to describe the actual cruelties endured by the animals - she did not want to be "carried away by the natural indignation caused by pictures of agony" (Studies 231) -, in 1883, after years of vain attempts at passing a Bill prohibiting vivisection, she actually used the description of those cruelties and the pictures of that agony as her method of exposition. In an attempt at counterbalancing the arguments of those who defended that vivisection was "almost wholly painless to the victims, and involves nothing more serious than 'scratching a newt's tail' or 'exhibiting a frog's foot under a microscope" (Light 31), Cobbe published twenty-three images and the accompanying descriptions of the tools, furniture, ways of fastening the animals, experiments - insisting that all had been taken from the vivisectors' own works, and depicting thus what she called "the work of the 'torture-chambers' of Science" (Light 3). The change in Cobbe's approach is also 
visible in her stand on the use of anaesthetics, which she considered a must for any experiment in the 1863 essay (Studies 239-240) but later on completely rejected. To make her point, she provided evidence given by physiologists on the uselessness of real anaesthetics, narcotics, and mock anaesthetics to prevent the agony of the animals (Light 4-7).

Cobbe's defence of animal rights and her radical opposition to the cruelty of vivisection is not devoid of some controverted stances mainly related to her upper-class view of the world. Thus, she stated in relation to the presence or absence of feelings of tenderness towards the brutes that "[W]e find as a rule that the most cultivated are the most merciful. But here there are also exceptions" (Studies 244), being the French men of science the exceptions considered. Fifteen years later, Cobbe would similarly blame artisans and the labouring classes in general for most of the cases related to wife-beating: "Wife-beating exists in the upper and middle classes rather more, I fear, than is generally recognized; but it rarely extends to anything beyond an occasional blow or two of a not dangerous kind" ("Wife-Torture" 58).

In this same spirit we see Cobbe making a clear distinction in her autobiography between the extreme barbarity of vivisection and the cruelty of upper-class field sports like hunting or shooting, which she just "dislikes". Her justification of the latter on class and gender grounds is paradigmatic of her approach to these and other issues:

When I was a little child, living in a house where hunting, coursing, shooting, and fishing, were carried on by all the men and boys, I took such field sports as part of the order of things, and learned with delight from my father to fish on our ponds on my own account. ... Of course, I disliked then, and always, hunting, coursing and shooting; but as a woman I was not expected to join in such pursuits, and I did not take on myself to blame those who followed them. I do not now allow of any comparison between the cruelty of such Field Sports and the deliberate Chamber-Sport of Vivisection. (Life 618-620)

These last lines serve us as an introduction to two very different essays, "Wife-Torture in England" (1878) and "Life in Donegal" (1866) which, in principle, would have little in common with Cobbe's antivivisectionist enterprise but which will reveal a series of concomitances behind most of the author's interests, namely those which concern us, the rights of animals, the rights of women, and the Irish question, thereby deploying a further instance of what Maureen O'Connor considers as "Cobbe's interconnected activisms" (43). Furthermore, the correlation in the author's interests is a clear manifestation of the connections between feminism and antivivisectionism that Lynda Birke and Carol Adams, among others, have explored.

\section{Like "watching a carter flogging a horse": The Claims of Women}

Frances Power Cobbe's name is usually brought up in discussions of the domestic ideology of Victorian England which she challenged by living thirty-four years with her female partner and participating actively in the suffragist cause. Notwithstanding, her undeniable interest in "women's affairs and claims" (Life 399) is rarely analysed in relation to her better-known facet as an animal's rights defender. It is precisely the aim of this section to determine the role played by environmental concerns and references to animals in her seminal essay "WifeTorture in England", published in 1878 and to assess the extent to which these derive from her main concern at the time of writing her essay, i.e. the antivivisection crusade she was involved in.

Cobbe herself established those links when she justified her title, choosing "wifetorture" instead of "wife-beating", which she defined as the mere "preface to the serious 
matter which is to follow", that of extreme cruelty ("Wife-Torture" 72). The more generalized use of the expression 'wife-beating' was discarded since it reminded Cobbe of the "candid and ingenuous vivisectors talk[ing] of 'scratching a newt's tail' when they refer to burning alive, or dissecting out the nerves of dogs, or torturing ninety cats in one series of experiments" ("Wife-Torture" 72). Having established this comparison, she went on to record twenty-eight reports of cases of extreme cruelty of husbands towards their wives which she had gathered from the newspapers over the course of a few months and that included cutthroating, choking and murder. This methodology is certainly relatable to the one she also employed for documenting the pain caused to animals in Light in Dark Places, as we have seen.

Furthermore, if Cobbe recurrently described vivisection in her autobiography not as a medical practice but rather as a "passion" that needed to be completely suppressed (Life 665), in "Wife-Torture in England" she linked both vivisection and wife-beating by referring to the former as "a new passion of cruelty" whereas the latter was considered as an age-old one "having its origin in the remotest epochs of barbarian wife-capture and polygamy" ("WifeTorture" 64). This interesting combination of allusions to domestic violence and to animal torture in Cobbe's works was materialized in the author's particular use of the term "heteropathy".

Cobbe's overall argument in her 1878 essay was that working-class women were the victims of violence at the hands of their husbands as a result of the polluted towns in which they lived, the absence of a legal support system for them, and other immediate causes like poisoned water, prostitution, sheer friction in the overcrowded homes of the poor, and "heteropathy" ("Wife-Torture" 65-66), a term she first employed in her essay "The Evolution of the Social Sentiment" first published in 1874 but that she explained more carefully in her autobiography when she described it as "that deep-seated animal instinct of hatred and anger against grief and suffering, the exact reverse of sympathy, which causes brutes and birds to gore and peck and slay their diseased and dying companions, and brutal men to trample on their weeping, starving wives" (Life 267). Cobbe recurrently linked "heteropathy" with the condition of many wives: "we do not hear of a regular system of strangling them when permanently diseased or incapacitated. They are only starved, beaten and overtaxed with toil, till they expire" (Hopes 162). Notwithstanding, she related these attitudes mainly to the lower classes and to the violence exerted by husbands over their wives as well as the violence of parents, step-parents, and schoolmasters over children (Hopes 172-174).

In "The Evolution of the Social Sentiment" she referred to her use of animal illustrations to make her points about violent human actions as her "method" (Hopes 179). And it is again the one she used four years later in "Wife-Torture in England", where Cobbe ended many of her arguments with an explicit allusion to the animal world. Therefore, when pointing at the indulgence with which the attacks on a wife by her husband are received by the general public, she mentions that they are as easily received as "watching a carter flogging a horse" ("Wife-Torture" 57). She even blames Shakespeare for including allusions to scenes of abuse between husbands and wives that emulate "the cracking of whips over the cowering dogs in a kennel" ("Wife-Torture" 57). As well as deploying Cobbe's commitment with ethics and morals, it is easy to devise in these recurrent interlacing of examples from the human and the animal world an application of the author's mindset at the time of writing her essay, when she was fully immersed in the antivivisection campaign. This is confirmed by what she writes on hearing about some instances of the successful application of the Separation Orders granted by the 1884 Act to Amend the Matrimonial Causes Act: "If I could hear before I die that I had been able to do as much for tortured brutes, I should say 'Nunc Dimittis' and wish no more" (Life 599). 
This is precisely what she was trying to do, to offer working class women the opportunity of legal separation as the most effective remedy to a problem she describes in detail, without forgetting to discuss the social class to which those brutal husbands belonged and the conditions in which they and their families lived, as well as the character of the men who beat their wives and that of the women who are beaten. In this respect, Cobbe considered that the corruption of the environment is partially responsible for cases of domestic violence provoked by working-class men. In her view, it was in the "great "hives of industry", that is Liverpool, Lancashire, Stafford, or Durham, where the proportion of brutal husbands was higher than anywhere else:

that Black Country where the green sod of earth is replaced by mounds of slag and shale, where no flower grows, no fruit ripens, scarcely a bird sings; where the morning has no freshness, the evening no dews; where the spring sunshine cannot pierce the foul curtain of smoke which overhangs these modern Cities of the Plain, and where the very streams and rivers run discoloured and steaming with stench. ("Wife-Torture" 59)

Furthermore, according to Cobbe, working-class women were also affected by this corrupt environment and she considered that at least half of them were unwomanly, bad, and cruel mothers who lived loose lives, terrible housekeepers who sold their clothes and furniture for gin. Thus, the gender negative stereotypes of "the Scold" and "the Nagging wife" were recalled by the author's description, although Cobbe did not go as far as to justify the treatment they received at the hands of their husbands. To the abovementioned class prejudice that we can detect in Cobbe's essay, one must add her racial prejudices: she holds that almost all the wife-beaters in the worst districts of London are Irishmen, corrupted by the influence of their dirty lodgings and hideous factories they worked in. Cobbe explains that contrary, to their attitude in England, Irishmen are always kind to women in Ireland ("Wife-Torture" 5859), making it difficult to ascertain her allegiances, as we will see when we discuss her imperialist reading of the Irish physical and human landscape in her essay "Life in Donegal" (1866) in the following section.

Her occasionally imperialist tone is also evident in those moments in which her claims against the abuse of women conflate with reflections on forms of enslavement. It is not devoid of contradictions that Cobbe avoids an equation between marriage and a master-slave relationship when referring to the case of upper classes ("Wife-Torture" 61), meanwhile she has recourse to the master-slave discourse when delving on working-class marriages. Thus, she compares the condition of these women to that of the Negroes in the plantations ("WifeTorture" 61), considering that their defence of their abusive husbands points at the iron fetters, like the slaves', that bind them to their ill-treaters ("Wife-Torture" 64), and she claims that marriage has become a type of "soul-degrading slavery" (Life 596) and that the eventual granting of Separation Orders to these tortured women is like the "manumission of ill-treated slaves" (Life 598).

Therefore, so as to free these new English slaves Cobbe asks for a Bill that gives them the same rights that wealthy women are given through the recently passed Divorce Law: a protection order, the custody of their children, and a weekly sum for their maintenance to be paid by the husband. "Wife-Torture in England" had indeed a great influence in the passing of the Matrimonial Causes Act of 1878, which gave wives the right to legal separation with maintenance, and the custody of any child under ten years of age. Unfortunately, Cobbe's fight for women's rights brought her the animadversion of many, as did her involvement in the antivivisection cause. Less problematic for the Victorian society were her views on the Irish Question, which interestingly show again points in common with Cobbe's two main interests already discussed. 


\section{"Beautiful in a certain wild desolate style": The Irish Question}

The prototypical imperialist view of Ireland in Victorian England was best illustrated by the numerous cartoons depicting the Irish as blacks, apes, or uncivilized savages, three images which are also apparent in Cobbe's texts. We have just seen moments of implicit comparison between the abused women, many of them Irish, and the black slaves in "Wife-Torture in England". In her autobiography, Cobbe makes a (certainly well-meant) comparison between the Irish peasants and animals when she claims that the hanging of a thief for stealing a sheep in the Ireland of the Famine was deemed a "necessary" measure by those unwilling to change the law, just as the scientific torture of animals was considered "necessary" in more recent times (Life 176-177). Later on, she depicts the society of Ireland in the late eighteenth century as a combination of aesthetic taste with barbarism (Life 17-18), a loaded word in Victorian England. Cobbe refers to the cottages in which her father's tenants lived as lacking the fine oak furniture that could be found in Welsh cottages: "Nothing seems to be more absurd and unhistorical than the common idea that the Celt is a beauty-loving creature, aesthetically far above the Saxon. If he be so, it is surprising that his home, his furniture, his dress, his garden never shows the smallest token of his taste!" (Life 141-142). A particular instance of this barbarism and of the incapacity of the Celts to live decently is the savage Donegal girl whom her brother had 'domesticated' [sic] and who had been given a neat cottage on occasion of her marriage which she left six months later in a poor condition: "the pig had slept all the time under the bedstead; and no attempt had been made to remove the resulting heap of manure!" (Life 142).

Frances Cobbe's essays on the Irish Question participate from this imperialist view of the natural and human landscape of Ireland, consubstantial with the author's birth and breeding, not a middle-class English reformer but belonging to the high-class Anglo-Irish. These circumstances put her in an ambivalent position. Indeed, in all her writings she counterbalances the negative clichés about the Irish that she seems to subscribe (that they are dirty, indolent, barbaric, treacherous, and ferocious) with other more favourable comparisons (as when she claims that vivisection had taken no hold in Ireland, or that teaching in Bristol schools was more difficult than teaching the Irish children, who were better at retaining knowledge). The main problem in Cobbe's approach derives from her attributing these good and bad qualities to racial prejudices.

At least six of Cobbe's essays written between 1865 and 1877 approached the Irish Question from very different perspectives, although they all share the common premise of vindicating Ireland as part of the British Empire.

"Life in Donegal", written and published in 1866, stands out as being more obviously environmentally-framed than the other five essays, and that is the reason why we consider it here in more detail. In this essay Cobbe combines allusions to a geographical and to an imagined Ireland that suits her own double condition as an Irish-born writer and as a "stranger" in Donegal, "stranger" being the term used by the Irish to refer to both the English and to the Anglo-Irish living in Ireland (Cameron 165). In what she calls a "true sketch of life in Donegal" ("Donegal" 436), that she addresses to those longing for visiting far-away places, she first provides a description of the county's lush natural beauties: "beautiful in a certain wild desolate style" ("Donegal" 436); presenting her own country as an exotic destination for English tourists where they could practice popular sports, fishing in particular. Notwithstanding, she warns her readers that the reality of a longer stay in Donegal soon counterbalances these amusements ("Donegal" 437). The absence of proper food and facilities is part and parcel of the deprivation endured by those living in Donegal, but what Cobbe laments the most is the difficulty to purchase the tools essential to an intellectual (books, 
paper, and ink) and the absence of educated people with whom to converse; in this respect, she dwells on how difficult it is for the Times to reach the place and reckons that no subscriber to the newspaper would be found in the whole county. This very British standard of a civilized life focused on reading and discussing the Times comes complete with scattered allusions in the essay to the weird use of the English language on the part of the inhabitants of Donegal: "those who were supposed to speak English called [salt sprats] "sprit"" ("Donegal" 437), a term she ironically repeats over and over. And when she fails to recall the name of a beautiful fish that was part of the catch of the Donegal fishermen, she adopts the position of the "stranger" saying that: "the Irish call it a Brazy" ("Donegal" 437).

Unsurprisingly for us at this stage, Cobbe's attitude comes across as ambivalent when we see her correcting the way in which the Londoners pronounce the name of Donegal and alluding to their ignorance of the history and geography of Ireland ("Donegal" 436). She is more direct in her criticism of their enthusiasm for open-air sports which involve preying on animals. Her involvement in the defence of animal rights had begun three years earlier, and the way she refers to the practitioners of these sports is indicative of what was to come in her public life:

that large proportion of English humanity which never thoroughly enjoys Nature unless it have a chance to strike out a few of her living beauties; to entrap one or two of the golden salmon darting among the deep dark pools; to stretch lifeless the playful brown hare leaping among the grass; to fill the boat with shuddering, gasping creatures, dragged by the net from the depths of the sea. ("Donegal" 436-437)

The opening lines of Cobbe's essay on Donegal offer an interesting instance of the method that Cobbe used in both her essays on heteropathy and on wife-torture: the parallel presentation of human activities and way of life, and those of animals, here representing the Cockney as a gregarious animal in words that seem to come from the voice of a naturalist:

At the end of the summer, that curious creature, the Cockney, undergoes a process corresponding partially to the hibernation of the mole, and partly to the passage of the herring. He ... seeks out a retired spot where he may burrow for a brief period in retirement. ("Donegal" 436)

To calm the English tourists' desire to enjoy the wilderness, she discusses her own country as an exotic destination. Indeed, she offers those desiring to travel to faraway places like New Zealand and Upper Canada the possibility of Donegal as a trial test for their capacity to live out of the world. If they can endure six months in that county, they can go anywhere ("Donegal" 436). The imperialist subtext in these statements is brought home with the closing words of the essay, when she quotes Lord Tennyson's "Better twenty years of Europe than a cycle of Cathay" ("Donegal" 438), Cobbe is actually taking Donegal out of Europe and assimilating it into China. She toys with maps again when she mentions the nineteenthcentury mapping of Ireland by the Ordnance Survey (carried out between 1825 and 1841), playfully doubting whether, taking into account the dissemination of the population, random villages have been invented and put in their charts.

The reader is left in no doubt that civilization is completely absent from Donegal and is sorely missed by this influential Irish Victorian activist who will, twelve years later, in her essay on wife-torture, surprisingly complain about the excessively populated and presumably more civilized cities where the corruption of the environment will cause the breakdown of the humanity of those inhabiting them and the ensuing ill-treatment of working-class women. These are the paradoxes in Cobbe's thought that we cannot turn a blind eye on. 


\section{Conclusion}

Frances Power Cobbe's life and work are beginning to receive the academic attention that her championship of "the rights of black slaves, working girls, women of all classes, and animals" (O’Connor 32) deserves. Notwithstanding, as Maureen O'Connor has sensibly argued, any rigorous approach to her activism should trace "some sources of the frustrated and sometimes crippling ideological inconsistencies and idiosyncrasies exhibited" (34) in her works. In the present case, we have seen how Frances Power Cobbe's class prejudice (as member of the Anglo-Irish Ascendancy) did not allow allow her to see clearly the connection between colonialism, women and animal cruelty, and class exploitation. Notwithstanding, many of her attitudes, discourses and methodologies, such as her conception of animals as sentient creatures, her ethics of justice and care towards non-human animals, and the parallelisms she established between the exploitation of and the violence exerted upon women and animals, can be considered as pioneer ideas that were later on more consistently developed by animal studies and by feminist animal studies.

\section{Works Cited}

Adams, Carol J. "Woman-Battering and Harm to Animals". Animals and Women. Feminist Theoretical Explorations. Ed. Carol J. Adams and Josephine Donovan. Durham \& London: Duke UP, 1995. 55-84.

Atkinson, Blanche. "Introduction". Life of Frances Power Cobbe as Told by Herself. Ed. Frances Power Cobbe and Blanche Atkinson. London: Sonnenschein \& Co., 1904. vxxix

Birke, Lynda. "Exploring the Boundaries: Feminism, Animals, and Science". Animals and Women. Feminist Theoretical Explorations. Ed. Carol J. Adams and Josephine Donovan. Durham \& London: Duke UP, 1995. 32-54.

Calarco, Matthew. Thinking Through Animals. Identity, Difference, Indistinction. Stanford, California: Stanford University Press, 2015.

Cameron, Kelly Jill. Imperial Rhetorics: Frances Power Cobbe's Answering of the Irish Question in the Nineteenth-Century Periodical Press. Ph.D. Thesis, Texas Christian University, 2012. https://repository.tcu.edu/handle/116099117/4381

Carvalho, André Luis de Lima \& Ricardo Waizbort. "Pain beyond the Confines of Man: A Preliminary Introduction to the Debate between Frances Power Cobbe and the Darwinists with Respect to Vivisection in Victorian England (1863-1904)". Transl. by Naomi Sutcliffe de Moraes. História, Ciências, Saúde. Manguinhos 17:3 (July-Sept. 2010): 577-605. https://www.scielo.br/pdf/hcsm/v17n3/en 02.pdf

Cobbe, Frances Power. "The Rights of Man and the Claims of Brutes" (1863). Studies New and Old on Ethical and Social Subjects. London: Trübner, 1865. 211-257.

."Life in Donegal". Once a Week (29 Oct. 1866): 436-438.

"The Evolution of the Social Sentiment". The Hopes of the Human Race, Hereafter and Here. London: Williams and Norgate, 1874. 149-218.

"Wife-Torture in England". The Contemporary Review, 1866-1900 32 (Apr. 1878): 55-87.

—. Light in Dark Places. London: Victoria Street Society, 1883.

- Life of Frances Power Cobbe, as Told by Herself, with Additions by the Author and Introduction by Blanche Atkinson. Posthumous edition. London: Swan Sonneschein, 1904.

Hamilton, Susan. Frances Power Cobbe and Victorian Feminism. New York: Palgrave Macmillan, 2006. 
Mitchel, Sally. Frances Power Cobbe: Victorian Feminist, Journalist, Reformer. Charlottesville \& London: U. of Virginia P. 2004.

O'Connor, Maureen. The Female and the Species: The Animal in Irish Women's Writing. Bern: Peter Lang, 2010.

Received: 07 August 2019 Revised version accepted: 22 September 2020

María José Carrera has a $\mathrm{PhD}$ in English Language and Literature and is Lecturer in Irish Literature at the University of Valladolid, Spain. She has published on Samuel Beckett's short prose and on his translations of Latin American poets. She is currently preparing a monograph on his work for An Anthology of Mexican Poetry (1958). Her research interests also include Irish literature, literary criticism and the critical edition of manuscripts.

mcarrera@fyl.uva.es 